\title{
Testing for Structural Changes in the Wagner's Law for a Sample of East Asian Countries
}

\author{
Saten Kumar and Zhaoyi Cao \\ School of Economics, Auckland University of Technology, New Zealand
}

First draft: 13 February 2012

This draft: 22 March 2019

\begin{abstract}
This paper examines the Wagner's Law for a sample of East Asian countries (China, Hong Kong, Japan and South Korea) by utilising the structural break methods viz., Gregory and Hansen (1996a \& b), Carrion-i-Silvestre and Sanso (2006) and Bai and Perron (1998 \& 2003). We find that there exists weak cointegrating relationship between the log of nominal public expenditure as a share of nominal GDP to the log of real per capita GDP. However, we find support for the Wagner's Law when the relationship is extended to include a measure of the population structure - the dependency ratio. Our findings support the explanations suggested by Durevall and Henrekson (2011).
\end{abstract}

Keywords: Government spending; Dependency ratio; Cointegration; Structural breaks

JEL: C22; H50 


\section{Introduction}

The link between public spending and economic growth received vast interest in the empirical literature. In the original study, Wagner (1883) formulated his famous law in which he argued, on the basis of several developed countries, that there is a positive long run relationship between public spending and national income. Wagner highlighted three main reasons for the increased government involvement in the economy (Henreksen, 1993). First, industrialization and modernization would lead to a substitution of public for private activity. Second, Wagner argued that the growth in real income would facilitate the relative expansion of income-elastic "cultural and welfare" expenditures. Finally, he asserted that economic development and changes in technology required government to take over the management of natural monopolies in order to enhance economic efficiency. The public spending in Wagner's Law is treated as an endogenous factor, that is, in the long run causality runs from national income to government spending. The basic Wagnerian assumption is that public spending increases at a faster rate than the growth of national income. From this perspective, Wagner quote this as "the law of increasing expansion of public, and particularly state, activities' becomes for the fiscal economy the law of the increasing expansion of fiscal requirements..." (Gemmell 1993, pp.104 and Muhlis and Hakan 2003, pp.58). However, an alternative explanation was postulated by Keynes (1936). Keynes argued that causality runs from government spending to national income. To this end, he asserted that fiscal policies boosts economic growth during a recession.

The relationship between government spending and national income is important for policy issues over the short to medium term. First, the Great Recession has strained many central authorities to amplify spending on required sectors. In this case, the empirical results based on Wagner's Law permits the respective governments to formulate a benchmark against which to evaluate the stance of expenditure policy and by and large fiscal policy. Second, this relation is relevant for the debate on the sustainability of public finances, especially during the phase when governments struggle to restrain the unwarranted spending. This relation, therefore, provides a framework to formulate appropriate budgetary adjustment plans with an outlook to attaining medium term budgetary objectives and/or reducing prolonged deficits. Because of these important policy implications, the validity of Wagner's Law should be tested within an adequate methodological framework.

This law, in spite of a number of empirical investigations with alternative specifications and estimation techniques, still remains popular, see for example Courakis et al. (1993), Cotsomitis et al. (1996), Ahsan et al. (1996), Ansari et al. (1997), Abizadeh and Yousefi (1998), Kolluri et al. (2000), Islam (2001), Chow et al. (2002), Burney (2002), Muhlis and 
Hakan (2003), Chang et al. (2004), Huang (2006), Sideris (2007), Sinha (2007), Narayan et al. (2007), Bose et al. (2007), Durevall and Henrekson (2011), Kuckuck (2012), Cavicchioli and Pistoresi (2016), and Funashima (2017). However, there are only a few studies that considered exploring the possibility of structural break in the cointegration relationship between government spending and income; see for example Durevall and Henrekson (2011), Kuckuck (2012) and Funashima (2017). This paper therefore fills this gap by examining the Wagner's Law for a sample of East Asian countries (China, Hong Kong, Japan, and South Korea) by utilizing the structural break methods viz., Gregory and Hansen (1996a \& b), Carrion-iSilvestre and Sanso (2006) and Bai and Perron (1998 \& 2003). Moreover, following Durevall and Henrekson (2011), we explore the usefulness of population structure (i.e. dependency ratio) in the cointegrating relationship of Wagner's Law. Our findings reveal that there is weak cointegration in the baseline model of Wagner's Law. In the other words, there exists weaker longrun relationship between the log of nominal public expenditure as a share of nominal GDP to the log of real per capita GDP. However, we find support for the Wagner's Law when the relationship is extended to include a measure of the population structure - the dependency ratio. This finding is consistent with Durevall and Henrekson (2011); that to attain a relationship between income and government spending, we need to control for the population structure.

The balance of this paper is organized as follows: Section 2 briefly provides an overview of the literature. Section 3 discusses the specification and methodology. Section 4 details empirical results and Section 5 concludes.

\section{Brief Review of Literature}

\subsection{Testing Wagner's Law without Structural Break Tests}

Early empirical literature on Wagner's Law utilised time series techniques without allowing for the possibility of structural breaks. Cotsomitis, Harnhirum and Kwan (1996) used data from China for the period 1952-92 to test the longrun co-movement of national income and government spending using the Engle and Granger technique. They find evidence in favour of Wagner's Law. Other similar studies also provide supporting evidence for Wagner's Law Ahsan, Kwan and Sahni (1996) for Canada, Koulluri, Panik and Wahab (2000) for G7 countries, Islam (2001) for the USA, Sideris (2007) for Greece, and Chang, Liu and Caudill (2004) for South Korea, Taiwan, Japan, the UK and the USA. Moreover, a number of studies find little evidence in favour of Wagner's Law, for example, Courakis, Moura-Roque and Tridimas (1993) for Greece and Portugal and Narayan, Nielsen and Smyth (2007) for Chinese provinces. By contrast, studies such as Ansari, Gordon, and Akuamoah (1997), Abizadeh and 
Yousefi (1998), Burney (2002), Chow, Cotsomitis and Kwan (2002), Muhlis and Hakan (2003), Chang et al. (2004), Huang (2006) and Sinha (2007) find no empirical support for Wagner's Law in countries such as China, South Africa, Thailand, New Zealand, Australia, Canada and the UK. For instance, Chow, Cotsomitis and Kwan (2002) used Johansen maximum likelihood (JML) procedure to examine Wagner's hypothesis in the UK for the period 1948 to 1997. Their baseline results revealed no support for Wagner's Law. However, when money supply is included in their model, there exists a longrun link between government spending and income in the UK. Pistoresi, Rinaldi and Salsano (2017) investigated the validity of Wagner's Law for Italy using the Dynamic Ordinary Least Squares technique. They find that Wagner's Law does not hold in the long run. However, they find strong support for Wagner's Law in the shorter time span from 1862 to the end of the 19th century.

\subsection{Testing Wagner's Law with Structural Break Tests}

There exist only a few studies that employed structural break tests to explore the validity of Wagner's Law. In an interesting study, Durevall and Henrekson (2011) investigated the validity of Wagner's Law for the U.K. and Sweden using the structural break methods. They find evidence in support of Wagner's Law between 1860 and the mid-1970s; however, they find no support for Wagner's Law in the beginning of the industrialization phase (before 1860) neither in the longrun. Kuckuck (2012) examined the Wagner's Law at three different stags (lower middle income, upper middle income and high income stage) of economic growth for five industrialized European countries (Denmark, Finland, Italy, Sweden and the U.K). Their analysis included structural break methods. They find that the association between government spending and economic growth has become weak during the last century. Keho (2016) employed the structural break techniques to test the longrun relationship between government spending and national income for six African countries (Benin, Cote d'Ivoire, Ghana, Kenya, Senegal and South Africa) for the period 1960 to 2013. He finds support for the Wagner's Law for only three countries (Ghana, Cote d'Ivoire and Kenya). Using the structural break methods, Funashima (2017) investigated the validity of Wagner's Law for 10 OECD countries. He finds little support for Wagner's Law in the earliest and advanced stages of economic growth. This finding is consistent with Durevall and Henrekson (2011), Lamartina and Zaghini (2011) and Kuckuck (2014). Moreover, Cavicchioli and Pistoresi (2016) examined the longrun relationship between Italian government spending and GDP. They find a threshold cointegrating relationship between government spending and economic growth. 
A few recent studies emphasize the importance of other variables in the Wagner's Law. For example, characteristics of fiscal discipline (Funashima and Hiraga, 2016) and age structure in the population (Shelton, 2007; Durevall and Henrekson, 2011) must be considered in the empirical examination of Wagner's Law. In general, the relationship that Wagner claimed is more powerful in the developed countries and weaker in the developing countries (Akitoby et al., 2006). However, in our knowledge, there are no studies that investigated the possibility of a structural break in the longrun cointegrating relationship of government spending and income for the East Asian countries. We attempt to fill this gap in the paper.

\section{Specification and Methodology}

\subsection{Model and Data}

The central issue in testing Wagner's Law is the choice of appropriate model specification. Following Durevall and Henrekson (2011), we specify two forms of Wagner's Law:

$$
\begin{array}{ll}
\text { Baseline Model: } & \ln G Y_{t}=\alpha+\beta_{0} \ln P c Y_{t}+\varepsilon_{t} \\
\text { Extended Model: } & \ln G Y_{t}=\alpha+\beta_{0} \ln P c Y_{t}+\beta_{1} \text { Dep Ratio }_{t}+\varepsilon_{t}
\end{array}
$$

where $\ln G Y=\log$ of nominal public expenditure as a share of nominal GDP, $\ln P c Y=\log$ of real per capita GDP, and Dep Ratio = dependency ratio, that is, those aged 0-19 and 65+, divided by those aged 20-64. $t$ is time subscript. $\varepsilon_{t}$ is $N(0, \sigma)$ for all $t$. The intercept parameter is $\alpha$. The marginal effect of real per capita income on nominal public expenditure as a share of GDP is captured the $\beta$ estimate. We expect the $\beta$ coefficient to be positive for the Wagner's Law to hold. We use annual time series data for the period 1960-2017 for four East Asian countries viz., China, Hong Kong, Japan and South Korea. Data is obtained from the World Development Indicators (WDI, 2018).

\subsection{Gregory and Hansen Structural Breaks}

Gregory and Hansen (1996a \& b) has developed a unique structural break test which accommodates a single endogenous break in an underlying cointegrating relationship. This technique is an extension of Zivot and Andrews (1992). Gregory and Hansen (GH henceforth) has proposed the following four models with alternative assumptions about structural breaks.

Model-I: Level shift

$Y_{t}=\mu_{1}+\mu_{2} \delta_{t p}+\alpha_{1} X_{t}+\varepsilon t$ 
Model-II: Level shift with trend

$Y_{t}=\mu_{1}+\mu_{2} \delta_{t p}+\beta_{1} t+\alpha_{1} X_{t}+\varepsilon_{t}$

Model-III: Regime shift where intercept and slope coefficients change

$Y_{t}=\mu_{1}+\mu_{2} \delta_{t p}+\beta_{1} t+\alpha_{1} X_{t}+\alpha_{11} X_{t} \delta_{t p}+\varepsilon t$

Model-IV: Regime shift where intercept, slope coefficients and trend change

$Y_{t}=\mu_{1}+\mu_{2} \delta_{t p}+\beta_{1} t+\beta_{2} t \delta_{t p}+\alpha_{1} X_{t}+\alpha_{11} X_{t} \delta_{t p}+\varepsilon t$

where $Y$ is the dependent variable, $X$ is the explanatory variable, $t$ is time subscript, $p$ is the break date, $\delta$ is a dummy variable and $\varepsilon$ is the error term, such that:

$\delta_{t p}=0$ if $t \leq p$ and $\delta_{t p}=1$ if $t>p$

The GH tests the null hypothesis of no cointegration with structural breaks against the alternative of cointegration. The break dates are found by estimating the cointegration equations for all possible break dates in the sample. We select a break date where the test statistic is the minimum or in other words the absolute ADF test statistic is at its maximum. GH have tabulated the critical values by modifying the MacKinnon (1991) procedure for testing cointegration with unknown breaks.

\subsection{Carrion-i-Silvestre and Sanso Structural Breaks}

Carrion-i-Silvestre and Sanso (2006) (CS, hereafter) has proposed structural tests for cointegration that explicitly takes into account endogenous break dates. It is particularly useful in the cases where standard cointegration methods yield no cointegration among the variables. This method allows for breaks in the cointegrating vectors of a relationship. The main advantage of this method is that it avoids the issue of disentangling a regime shift from a stable cointegrating relationship as is the case in the GH tests. Note that GH's alternative hypothesis allows for cointegration with breaks but also includes the stable cointegrating relation in the alternative hypothesis; see Beyer et al. (2009) for more details.

The null hypothesis tests for a cointegrating relation in the presence of one break against the alternative of no cointegration (with one break). CS test is a Lagrange-Multiplier-type (LM) test that is estimated from the Dynamic Ordinary Least Squares (DOLS) residuals and the related long run variance-covariance matrix. Bartlett kernel window is utilised to estimate the 
matrix (non-parametrically) and the selection of the optimal spectral bandwidth is based on a data-dependent procedure; see Kurozumi (2002). The unknown break dates are estimated with the dynamic algorithm of Bai and Perron $(1998,2003)$ and this reduces the sum of squared residuals from DOLS regressions over a closed subset of break fractions. We apply CS tests for structural breaks in the intercept, trend as well as slope parameters. The critical values for this test are provided in Carrion-i-Silvestre and Sanso (2006).

\subsection{Multiple Structural Breaks}

Bai and Perron's $(1998,2003)$ (BP, henceforth) model of multiple structural breaks is widely used in the cointegration analysis. BP's method also assumes that potential structural break points are unknown. This method is similar to Lee and Strazicich (2003) and Lumsdaine and Papell (1997) tests, except that BP offers multiple endogenous breaks in the data series. This method does not test for breaks in cointegrating vectors but instead tests for the existence of multiple structural breaks in the data series which is enhancing especially in long run time series analysis where different factors might affect the behaviour of tested data in different time periods.

The multiple linear regression system can be expressed in matrix form as:

$Y=X \beta+\bar{Z} \delta+U$

where $Y=\left(y_{1}, \ldots, y_{T}\right)^{\prime}, X=\left(x_{1}, \ldots, x_{T}\right)^{\prime}, U=\left(u_{1}, \ldots, u_{T}\right)^{\prime}, \delta=\left(\delta_{1}^{\prime}, \delta^{\prime}{ }_{2}, \ldots, \delta^{\prime}{ }_{m+1}\right)^{\prime}$, and $\bar{Z}$ is the matrix which diagonally partitions $\mathrm{Z}$ at the m-partition $\left(T_{1}, \ldots, T_{m}\right)$, ie., $\bar{Z}=\operatorname{diag}\left(Z_{1}, \ldots, Z_{m+1}\right)$ with $Z_{i}=\left(z_{T_{i-1}+1}, \ldots, z_{T_{i}}\right)^{\prime}($ Bai and Perron, 2003, pp. 3). The model estimation is based on the least squares principle. For each m-partition $\left(T_{1}, \ldots, T_{m}\right)$ denoted $\left\{\mathrm{T}_{\mathrm{j}}\right\}$, the associated least squares estimates of $\beta$ and $\delta$ are attained by minimizing the sum of squared residual as follows:

$$
S S R=\sum_{i=1}^{m+1} \sum_{t=T_{i-1}+1}^{T_{i}}\left[y_{t}-x_{t}^{\prime} \beta-z_{t}^{\prime} \delta_{i}\right]^{2}
$$

The resulting coefficients are denoted by $\hat{\beta}\left(\left\{T_{j}\right\}\right)$ and $\hat{\delta}\left(\left\{T_{j}\right\}\right)$ and substituting them in the objective function gives the following break-point estimator: 


$$
\left(\hat{T}_{1}, \ldots, \hat{T}_{m}\right)=\arg \min _{T 1, \ldots, T m} S_{T}\left(T_{1}, \ldots, T_{m}\right)
$$

where the sum of squared residuals and the estimated break points are $S_{T}\left(T_{1}, \ldots, T_{m}\right)$ and $\left(\hat{T}_{1}, \ldots, \hat{T}_{m}\right)$, respectively. The minimization is performed over all partitions $\left(T_{1}, \ldots, T_{m}\right)$ such that $T_{i}-T_{i-1} \geq q$. The regression parameter estimates at estimated $m$-partition $\left\{\hat{T}_{j}\right\}$ are $\hat{\beta}=\hat{\beta}\left(\left\{\hat{T}_{j}\right\}\right)$ and $\hat{\delta}=\hat{\delta}\left(\left\{\hat{T}_{j}\right\}\right)$. Note that the break point estimators are global minimizers and the break-points are estimated using a dynamic programming algorithm. BP has suggested the following methods to determine the existence of structural breaks in the data series: (1) let the sup $F_{t}(m)$ denote the F statistic for testing $H_{0}$ : no breaks against $H_{1}: m$ breaks, (2) UD max and WD max represents double maximum statistics and the weights double maximum statistic, respectively, and these are used for testing the $H_{0}$ : no breaks against $H_{1}: 1 \leq m \leq M$ breaks $^{1}$ and (3) $\sup F_{T}(m+1 \mid \mathrm{m})$ denotes the $F$ statistics for testing the $H_{0}: m$ breaks against $H_{1}: m+1$ breaks.

\section{Empirical Results}

\subsection{Unit Root Tests}

We first test for stationarity properties of the variables. Specifically, we use the Augmented Dicky Fuller $(A D F)$ and Phillips Perron $(P P)$ tests and the results are reported in Table 1. The $A D F$ tests have been applied for both levels and their first differences with an intercept and trend. The $A D F$ and $P P$ statistics for the level variables $(\ln \underline{G Y}, \ln P c Y$, and Dep Ratio) do not exceed the critical values (in absolute terms). However, when we take the first difference of each of the variables, the $A D F$ and $P P$ statistics are higher than the respective critical values (in absolute terms). Therefore, in all cases the level variables are $I(1)$ and their first differences are $I(0)$.

\{Insert Table 1 about here

\subsection{Gregory and Hansen Tests}

In what follows, we report our $G H$ results. The four models of $G H$ (equations $3-6$ ) are estimated from 1960-2017. The results are presented in Table 2. In the baseline model, the

\footnotetext{
${ }^{1} M$ is the upper bound on the number of possible breaks.
} 
null hypothesis of no cointegration cannot be rejected in majority of the $G H$ models. The only exceptions are China and Japan where Model-I supports the existence of a longrun relationship between $G Y$ and $P c Y$. On the other hand, we find evidence of cointegration in the extended model in all cases. To this end, the null hypothesis of no cointegration is rejected in all the models of $G H$. Next, using the estimation method proposed by $G H$, we estimate the cointegrating equations for the models in which cointegration exists. These results are reported in Tables 3-5. The income elasticity of government spending is around 0.8 and 0.9 for China and Japan, respectively. Further, the income elasticity is around unity for Hong Kong and South Korea. The elasticity with respect to dependency ratio is around 0.3 for China, 0.8 for Hong Kong and 0.7 for Japan and South Korea, respectively. The income and dependency ratio elasticities are statistically significant at the conventional levels. With these findings, we infer that Wagner's Law does hold for the East Asian countries, however, it is useful to consider the population structure in the cointegrating relationship of Wagner's Law.

\{Insert Tables 2-5 about here $\}$

\subsection{Carrion-i-Silvestre and Sanso Tests}

Application of CS tests revealed that the null of cointegration with a structural break is rejected at 5\% level in the baseline model. However, cointegration test results in the extended model are opposite. On this front, the null of cointegration with a structural break cannot be rejected at the 5\% level in the baseline model. Table 6 reports the CS test statistics and break dates. The DOLS regressions are vital for performing the CS break tests. We used 4 leads and lags in DOLS regressions and varying these lags provided same qualitative results. Following Beyer et al. (2009) and Andrews (1991) the long run variances are estimated with a quadratic spectral kernel and automatic bandwidth selection after autoregressive pre-whitening. CS has noted that the use of the standard automatic bandwidth selection methods leads to an inconsistent test. The CS test results are very consistent with the GH test results.

\{Insert Table 6 about here $\}$

\subsection{Bai and Perron Tests}

The GH and CS tests fail to detect multiple structural breaks and we therefore further employ the BP test to investigate the unknown multiple breaks in the data series. The BP test results are reported in Table 7. Application of BP tests to the data revealed the existence of two breaks 
in $\ln G Y$ and $\ln P c Y$ in all cases, except for Japan where three breaks in the series are depicted. The double maximum tests of UDmax and WDmax rejects the null of no breaks against the unknown number of breaks given the upper bound of five breaks. It is well known that the significance of these tests does not give much information about the exact number of breaks, but implies that one break is at least present. In our case, both the UDmax and WDmax tests provide evidence of multiple structural breaks at the 5\% level. The $\operatorname{Sup} F(2 \mid 1)$ tests were rejected for the null of 1 break against the alternative of 2 breaks in the case of China, Hong Kong and South Korea. However, the null cannot be rejected for Sup F(3|2) tests for these three countries. In the case of Japan, the Sup F(3|2) tests were rejected for the null of 2 breaks against the alternative of 3 breaks; and the null cannot be rejected for $\operatorname{Sup} F(4 \mid 3)$ test. The multiple break dates, which are consistent with the GH and CS, seems to be related to economic incidents of these countries; we discuss the break dates in the following section.

\{Insert Table 7 about here $\}$

\subsection{Possible Explanations of Break Dates}

We find the structural breaks depicted by GH, CS and BP tests are fairly consistent. Table 8 presents the possible explanations of the break dates. All three tests revealed that there is a break in 1997-1999 and 2008-2009 in all selected countries. This draws our attention to the Asian financial crisis and the Great Recession. During the period 1997-1999, East Asia was gripped by an economic and political crisis. Major companies were defaulted on their foreign debt repayments that resulted in lower investment, employment and output growth. Although the East Asian countries were not at the center of the Great Recession, they did experience the effects of the recession through both the trade and financial channels, reflecting the region's deep economic integration with the rest of the world. Their exports tumbled, average sovereign credit default swap spreads increased enormously, and stock prices fell sharply. Exchange rates, employment, and output growth also came under pressure in a number of East Asian countries. We treat both events (Asian financial crisis and the Great Recession) as a temporary shock. To this end, they have not induced any permanent structural breaks in the cointegrating relationship of Wagner's Law.

\{Insert Table 8 about here $\}$ 


\section{Conclusion}

In this paper, we examined the Wagner's Law for a sample of East Asian countries (China, Hong Kong, Japan, and South Korea) using three structural break methods viz., Gregory and Hansen (1996a \& b), Carrion-i-Silvestre and Sanso (2006) and Bai and Perron (1998 \& 2003). The Gregory and Hansen and Carrion-i-Silvestre and Sanso tests revealed that there exists weak cointegrating relationship between the log of nominal public expenditure as a share of nominal GDP to the log of real per capita GDP. However, we find support for the Wagner's Law when the relationship is extended to include a measure of the population structure - the dependency ratio. This finding is consistent with Durevall and Henrekson (2011). Furthermore, the income elasticity of government spending is around 0.8 and 0.9 for China and Japan, respectively. For Hong Kong and South Korea, the income elasticity is around unity. The elasticity with respect to dependency ratio is around 0.3 for China, 0.8 for Hong Kong and 0.7 for Japan and South Korea, respectively. With these findings, we conclude that Wagner's Law does hold for the East Asian countries. The break dates are fairly consistent across the three methods; most break dates indicate the East Asian countries experience in the Asian financial crisis and the Great Recession.

Our main finding stresses that dependency ratio play an important role in the Wagner's Law. There arises a key policy implication from this finding, i.e., there will be greater demands placed on the fiscal policy if there is an increase in the dependency ratio. The governments are committed to paying a state pension and related benefits. An increase in the dependency ratio would imply higher government spending and this may put pressures on government finances and ultimately lead to higher tax rates on a declining working population. On the other hand, a fall in the dependency ratio would imply lower burden on the fiscal policy. To this end, the governments may end up spending less on pension and retirement benefits. This may put less pressures on government finances. 
Compliance with Ethical Standards:

(In case of Funding) Funding: This study was funded by X (grant number X). No funding received.

Conflict of Interest: Author A has received research grants from Company A. Author B has received a speaker honorarium from Company $\mathrm{X}$ and owns stock in Company $\mathrm{Y}$. Author $\mathrm{C}$ is a member of committee Z. OR if no conflict exists: Author A declares that he/she has no conflict of interest. Author B declares that he/she has no conflict of interest. ... Saten Kumar declares no conflict of interest. Zhaoyi Cao declares no conflict of interest.

(In case animals were involved) Ethical approval: All applicable international, national, and/or institutional guidelines for the care and use of animals were followed. Not applicable.

(And/or in case humans were involved) Ethical approval: All procedures performed in studies involving human participants were in accordance with the ethical standards of the institutional and/or national research committee and with the 1964 Helsinki declaration and its later amendments or comparable ethical standards. Not applicable.

(If articles do not contain studies with human participants or animals by any of the authors, please select one of the following statements) Ethical approval: This article does not contain any studies with human participants performed by any of the authors. 


\section{References}

Abizadeh, S. and Yousefi, M. (1998) 'An empirical analysis of South Korea's economic development and public expenditures growth', Journal of Socio-Economics, 27, 687700 .

Ahsan, M., Kwan, A. C. and Sahni, B. S. (1996) 'Cointegration and Wagner's hypothesis: time series evidence for Canada', Applied Economics, 28, 1055-1058.

Akitoby, B., Clements, B., Gupta, S., \& Inchauste, G. (2006). Public spending, voracity, and Wagner's law in developing countries. European Journal of Political Economy, 22(4), 908-924.

Andrews, D. W. (1991). Heteroskedasticity and autocorrelation consistent covariance matrix estimation. Econometrica: Journal of the Econometric Society, 817-858.

Ansari, M. I., Gordon, D. V. and Akuamoah, C. (1997) 'Keynes versus Wagner: public expenditure and national income for three African countries', Applied Economics, 29, 543-550.

Bai, J. and Perron, P. (2003) 'Computation and analysis of multiple structural change models,' Journal of Applied Econometrics, 18, 1-22.

(1998) 'Estimating and testing linear models with multiple structural changes,' Econometrica, 66, 47-78.

Beyer, A., Haug, A.A., Dewald, W.G. (2009) 'Structural breaks, cointegration and the Fisher effect,'European Central Bank Working Paper No. 1013, pp. 4-29.

Bose, N., Haque, M. E., \& Osborn, D. R. (2007). Public expenditure and economic growth: A disaggregated analysis for developing countries. The Manchester School, 75(5), 533556.

Burney, N. A. (2002) 'Wagner's hypothesis: evidence from Kuwait using cointegration tests', Applied Economics, 34, 49-57.

Carrion-i-Silvestre, J.L. and Sanso, A. (2006) 'Testing the null of cointegration with structural breaks,'Oxford Bulletin of Economics and Statistics, 68, 623-646.

Cavicchioli, M., \& Pistoresi, B. (2016). Testing threshold cointegration in Wagner's Law: The role of military spending. Economic Modelling, 59, 23-31.

Chang, T., Liu, W. and Caudill, S. (2004) 'A re-examination of Wagner's Law for ten countries based on cointegration and error-correction modeling techniques', Applied Financial Economics, 14, 577-589.

Chow, Y., Cotsomitis, J.A. and Kwan, A.C. (2002) 'Multivariate cointegration and causality tests of Wagner's hypothesis: evidence from the UK', Applied Economics, 34, 16711677.

Cotsomitis, J.A., Harnhirun, S. and Kwan, A.C. (1996) 'Co-integration analysis and the long run validity of Wagner's hypothesis: evidence from the People's Republic of China', Journal of Economic Development, 21, 1-10.

Courakis, A. S., Moura-Roque, F. and Tridimas, G. (1993) 'Public expenditure growth in Greece and Portugal: Wagner's Law and beyond', Applied Economics, 25, 125-134.

Durevall, D., \& Henrekson, M. (2011). The futile quest for a grand explanation of long-run government expenditure. Journal of Public Economics, 95(7-8), 708-722.

Funashima, Y. (2017). Wagner's law versus displacement effect. Applied Economics, 49(7), 619-634.

Funashima, Y., \& Hiraga, K. (2017). Wagner's law, fiscal discipline, and intergovernmental transfer: empirical evidence at the US and German state levels. International Tax and Public Finance, 24(4), 652-677.

Gemmell, N. (ed) (1993) 'The Growth of the Public Sector: Theories and International Evidence', Edward Elgar.

Gregory, A.W. and Hansen, B.E. (1996a) 'Residual-based tests for cointegration in models with regime shifts,'Journal of Econometrics, 70, 99-126. 
$-(1996 b)$ 'Tests for cointegration in models with regime and trend shifts', Oxford Bulletin of Economics and Statistics, 58, 555-559.

Henrekson M. (1993) 'Wagner's law- A spurious relationship?' Public Finance, 48, 406-415. Huang, C. (2006) 'Government expenditures in China and Taiwan: do they follow Wagner's Law?' Journal of Economic Development, 31, 139-147.

Islam, A.M. (2001) 'Wagner's Law revisited: cointegration and exogeneity tests for USA', Applied Economics, 8, 509-515.

Keho, Y. (2016) 'Testing Wagner's Law in the Presence of Structural Changes: New Evidence from Six African Countries (1960-2013)', International Journal of Economics and Financial Issues, 6, 1-6.

Keynes, J.M. (1936) 'The General Theory of Employment Interest and Money', New York: Harcourt, Brace \& World Inc.

Kolluri, B. R., Panik, M. J. and Wahab, M. S. (2000) 'Government expenditure and economic growth: evidence from G7 countries', Applied Economics, 32, 1059-1068.

Kuckuck, J. (2012). Testing Wagner's law at different stages of economic development: $A$ historical analysis of five Western European countries (No. 91). Working Paper, Institute of Empirical Economic Research, University of Osnabrück.

Kurozumi, E. (2002) 'Testing for stationarity with a break,' Journal of Econometrics, 108, 6399.

Lamartina, S., \& Zaghini, A. (2011). Increasing public expenditure: Wagner's law in OECD countries. German Economic Review, 12(2), 149-164.

Lee, J. and Strazicich, M.C. (2003) 'Minimum Lagrange multiplier unit root test with two structural breaks,'Review of Economics and Statistics, 85, 1082-89.

Lumsdaine, R. L and Papell, D. H. (1997) 'Multiple trend breaks and the unit root hypothesis,' Review of Economics and Statistics, 79, pp. 212-218.

MacKinnon, J. G. (1991) 'Critical values for cointegration tests', in Engle, R. F. and Granger, C.W.J. (eds), Long run Economic Relationships: Readings in Cointegration, Oxford University Press, 267-276.

Muhlis, B. and Hakan, C. (2003) 'Causality between public expenditure and economic growth: the Turkish case', available at http://mpra.ub.uni-muenchen.de/8576/.

Narayan, P.K., Nielsen, I. and Smyth, R. (2007) 'Panel data, cointegration, causality and Wagner's Law: empirical evidence from Chinese provinces', China Economic Review, 19, 297-307.

Peacock, A. and Scott, A. (2000) 'The curious attraction of Wagner's Law', Public Choice, 102, 1-17. Peacock, A. and Wiseman, J. (1961) 'The growth of public expenditure in the United Kingdom', Princeton University Press, Princeton.

Pistoresi, B, Rinaldi, A., and F. Salsano (2017) 'Government spending and its components in Italy, 1862-2009: Drivers and policy implications,' Journal of Policy Modeling, 39(6), $1117-1140$.

Shelton, C. A. (2007). The size and composition of government expenditure. Journal of Public Economics, 91(11-12), 2230-2260.

Sideris, D. (2007) 'Wagners Law in 19th century Greece: a cointegration and causality analysis', Bank of Greece working paper No. 64, Bank of Greece.

Sinha, D. (2007) 'Does the Wagner's Law hold for Thailand? a time series study', available at http://econpapers.repec.org/paper/pramprapa/2560.htm.

Wagner, A. (1883) 'Three extracts on public finance', in R. A. Musgrave and A. T. Peacock (eds) (1958), Classics in the Theory of Public Finance. London: Macmillan.

World Development Indicators, 2008. WDI Online Database (Washington DC: The World Bank).

Zivot, E. and Andrews, D.W. (1992) 'Further evidence on the great crash, the oil-price shock, and the unit root hypothesis', Journal of Business and Economic Statistics, 10, 251-270. 
Table 1. Results of ADF and PP Unit Root Tests 1960-2017

\begin{tabular}{|c|c|c|c|c|c|c|}
\hline Variables & $\ln G Y$ & $\Delta \ln G Y$ & $\ln P c Y$ & $\Delta \ln P c Y$ & Dep Ratio & $\Delta D e p$ Ratio \\
\hline \multicolumn{7}{|l|}{ China } \\
\hline ADF Statistic & $2.210[2]$ & $3.880[1]$ & $0.625[0]$ & $4.227[1]$ & $1.262[1]$ & $5.228[1]$ \\
\hline PP Statistic & $0.695[1]$ & $6.322[3]$ & 1.147 [2] & $8.190[3]$ & 0.874 [2] & 3.874 [2] \\
\hline \multicolumn{7}{|l|}{ Hong Kong } \\
\hline ADF Statistic & $0.558[0]$ & 7.215 [2] & $1.003[1]$ & $3.950[0]$ & $0.641[1]$ & $4.517[0]$ \\
\hline PP Statistic & $3.014[1]$ & $5.623[4]$ & $0.785[1]$ & $6.011[2]$ & 0.299 [3] & $9.016[5]$ \\
\hline \multicolumn{7}{|l|}{ Japan } \\
\hline ADF Statistic & $2.166[0]$ & $3.672[0]$ & 3.015 [2] & $4.525[1]$ & $2.576[2]$ & $4.004[1]$ \\
\hline PP Statistic & $1.021[3]$ & $4.355[2]$ & $2.544[4]$ & $7.344[4]$ & $0.870[4]$ & $4.025[2]$ \\
\hline \multicolumn{7}{|l|}{ South Korea } \\
\hline ADF Statistic & $0.964[1]$ & $5.247[1]$ & $0.630[1]$ & $3.700[1]$ & $1.117[1]$ & $5.382[0]$ \\
\hline PP Statistic & $0.570[4]$ & $9.360[3]$ & $1.238[2]$ & $6.009[3]$ & $2.690[2]$ & $7.204[2]$ \\
\hline
\end{tabular}


Table 2. Cointegration Tests with Structural Breaks 1960-2017

\begin{tabular}{|c|c|c|c|c|c|c|c|c|}
\hline & \multicolumn{4}{|c|}{ Baseline Model: $\ln G Y_{t}=\alpha+\beta_{0} \ln P c Y_{t}+\varepsilon_{t}$} & \multicolumn{4}{|c|}{ Extended Model: $\ln G Y_{t}=\alpha+\beta_{0} \ln P c Y_{t}+\beta_{1}$ Dep Ratio ${ }_{t}+\varepsilon_{t}$} \\
\hline & Break Date & $\begin{array}{l}\text { GH Test } \\
\text { Statistic }\end{array}$ & $\begin{array}{l}5 \% \text { Critical } \\
\text { Value }\end{array}$ & $\begin{array}{c}\text { Existence of } \\
\text { Cointegration? }\end{array}$ & Break Date & $\begin{array}{l}\text { GH Test } \\
\text { Statistic }\end{array}$ & $\begin{array}{l}5 \% \text { Critical } \\
\text { Value }\end{array}$ & $\begin{array}{c}\text { Existence of } \\
\text { Cointegration? }\end{array}$ \\
\hline \multicolumn{9}{|l|}{ China } \\
\hline Model-I & 1987 & -5.23 & -4.61 & Yes & 1997 & -5.36 & -4.92 & Yes \\
\hline Model-II & 2008 & -0.98 & -4.99 & No & 1998 & -7.15 & -5.29 & Yes \\
\hline Model-III & 1984 & -3.06 & -4.61 & No & 1985 & -6.02 & -5.29 & Yes \\
\hline Model-IV & 1997 & -2.23 & -4.99 & No & 2009 & -5.08 & -4.61 & Yes \\
\hline \multicolumn{9}{|c|}{ Hong Kong } \\
\hline Model-I & 1995 & -1.24 & -4.95 & No & 1997 & -8.22 & -4.61 & Yes \\
\hline Model-II & 1985 & -1.66 & -5.29 & No & 1998 & -7.14 & -5.50 & Yes \\
\hline Model-III & 2008 & -2.50 & -5.50 & No & 2009 & -7.85 & -5.50 & Yes \\
\hline Model-IV & 1997 & -2.75 & -5.50 & No & 2008 & -6.74 & -5.29 & Yes \\
\hline \multicolumn{9}{|l|}{ Japan } \\
\hline Model-I & 2009 & -7.95 & -4.92 & Yes & 2008 & -5.61 & -4.92 & Yes \\
\hline Model-II & 1989 & -3.11 & -5.29 & No & 1998 & -8.30 & -5.29 & Yes \\
\hline Model-III & 1998 & -1.36 & -5.29 & No & 1989 & -10.25 & -4.92 & Yes \\
\hline Model-IV & 1992 & -1.57 & -4.61 & No & 1992 & -4.95 & -4.92 & Yes \\
\hline \multicolumn{9}{|c|}{ South Korea } \\
\hline Model-I & 2002 & -2.36 & -4.95 & No & 2003 & -7.05 & -4.61 & Yes \\
\hline Model-II & 1998 & -1.47 & -4.61 & No & 1998 & -7.41 & -5.29 & Yes \\
\hline Model-III & 2003 & -2.55 & -4.99 & No & 2009 & -8.36 & -5.29 & Yes \\
\hline Model-IV & 2009 & -1.68 & -4.99 & No & 2002 & -5.47 & -4.95 & Yes \\
\hline
\end{tabular}


Table 3. Cointegrating Equations in Baseline Model 1960-2017

Baseline Model: $\ln G Y_{t}=\alpha+\beta_{0} \ln P c Y_{t}+\varepsilon_{t}$

\begin{tabular}{lcc}
\hline & China & Japan \\
& Model-I & Model-I \\
\hline Intercept & -1.236 & 4.351 \\
& $(0.35)$ & $(0.07)^{*}$ \\
DUM * Intercept & -0.669 & 1.200 \\
& $(0.08)^{*}$ & $(0.09)^{*}$ \\
$\ln P c Y$ & 0.756 & 0.901 \\
& $(0.04)^{* *}$ & $(0.00)^{* * *}$ \\
\hline
\end{tabular}

Notes: p-values are reported in parentheses. $*, * *, * * *$ indicates statistical significance at $10 \%, 5 \%$, and $1 \%$ levels, respectively. Model-I is the level shift. 
Table 4. Cointegrating Equations in Extended Model, China and Hong Kong

Extended Model: $\ln G Y_{t}=\alpha+\beta_{0} \ln P c Y_{t}+\beta_{1}$ Dep Ratio ${ }_{t}+\varepsilon_{t}$

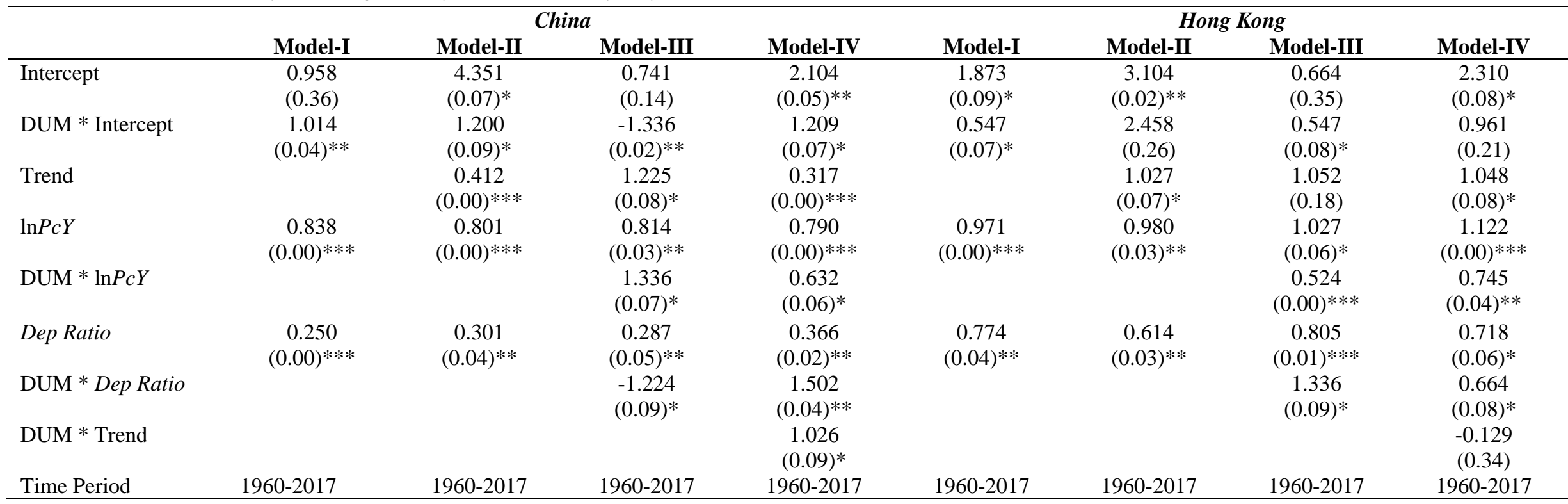

Notes: p-values are reported in parentheses. *,**,*** indicates statistical significance at $10 \%, 5 \%$, and $1 \%$ levels, respectively. Model-I is the level shift. Model-II is the level shift with trend. Model-III is the regime shift where intercept and slope coefficients change. Model-IV is the regime shift where intercept, slope coefficients, and trend change. 
Table 5. Cointegrating Equations in Extended Model, Japan and South Korea

Extended Model: $\ln G Y_{t}=\alpha+\beta_{0} \ln P c Y_{t}+\beta_{1}$ Dep Ratio ${ }_{t}+\varepsilon_{t}$

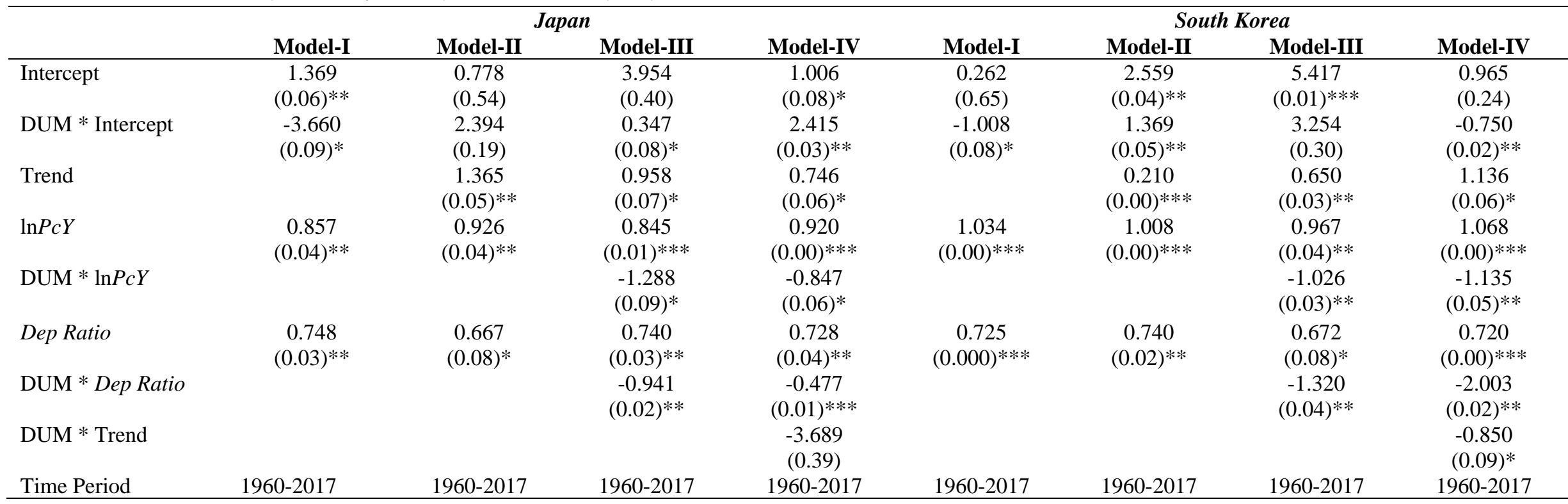

Notes: p-values are reported in parentheses. *,**,*** indicates statistical significance at $10 \%, 5 \%$, and $1 \%$ levels, respectively. Model-I is the level shift. Model-II is the level shift with trend. Model-III is the regime shift where intercept and slope coefficients change. Model-IV is the regime shift where intercept, slope coefficients, and trend change. 
Table 6. Carrion-i-Silvestre and Sanso Structural Break Tests 1960-2017

\begin{tabular}{llclc}
\hline & \multicolumn{2}{l}{ Baseline Model: } & \multicolumn{2}{l}{ Extended Model: } \\
& $\ln G Y_{t}=\alpha+\beta_{0} \ln P c Y_{t}+\varepsilon_{t}$ & \multicolumn{2}{l}{$\ln G Y_{t}=\alpha+\beta_{0} \ln P c Y_{t}+\beta_{1}$ Dep Ratio $_{t}+\varepsilon_{t}$} \\
\hline Country & Test Statistic & Break Date & Test Statistic & Break Date \\
China & $0.316^{*}$ & 1998 & 0.052 & 2009 \\
Hong Kong & $0.208^{*}$ & 1997 & 0.061 & 1997 \\
Japan & $0.458^{*}$ & 1992 & 0.074 & 1998 \\
South Korea & $0.267^{*}$ & 2008 & 0.057 & 1998 \\
\hline
\end{tabular}

Notes: The null hypothesis is cointegration with break at unknown point. Critical values are provided in Carrioni-Silvestre and Sansó's (2006) Table 2. * denotes that the null hypothesis is rejected. 
Table 7. Bai and Perron Structural Break Tests 1960-2017

\begin{tabular}{|c|c|c|c|c|c|c|c|c|}
\hline & $U D \max$ & WDmax & $\operatorname{SupF(1|0)}$ & $\operatorname{SupF(2|1)}$ & $\operatorname{SupF(3|2)}$ & SupF $(4 \mid 3)$ & $\operatorname{SupF}(5 \mid 4)$ & $\overline{\text { Break Dates }}$ \\
\hline \multicolumn{9}{|l|}{ China } \\
\hline $\ln G Y$ & $137.127 *$ & $142.236^{*}$ & $57.201 *$ & $44.013 *$ & 7.658 & 6.360 & 1.554 & $1985 ; 2009$ \\
\hline $\ln P c Y$ & $247.012 *$ & $271.530^{*}$ & $38.474^{*}$ & $37.985^{*}$ & 9.277 & 7.660 & 4.574 & 1998; 1999 \\
\hline Dep Ratio & 37.541 & 24.850 & 10.451 & 4.018 & 3.587 & 3.211 & 3.593 & - \\
\hline \multicolumn{9}{|l|}{ Hong Kong } \\
\hline $\ln G Y$ & $183.374 *$ & $136.115^{*}$ & $62.534 *$ & $76.009 *$ & 27.115 & 10.009 & 6.159 & 1997; 1998 \\
\hline $\ln P c Y$ & $205.285^{*}$ & $328.210^{*}$ & $88.279 *$ & $32.519 *$ & 28.489 & 5.381 & 7.290 & $1997 ; 2009$ \\
\hline Dep Ratio & 48.300 & 32.018 & 8.114 & 7.325 & 4.110 & 4.055 & 1.247 & - \\
\hline \multicolumn{9}{|l|}{ Japan } \\
\hline $\ln G Y$ & $275.369 *$ & $247.320 *$ & $61.024 *$ & $48.007 *$ & $30.960 *$ & 9.016 & 3.205 & 1989;1998; 2008 \\
\hline $\ln P c Y$ & $196.248 *$ & $167.025 *$ & $39.026^{*}$ & $41.096^{*}$ & $41.283^{*}$ & 4.002 & 3.354 & $1992 ; 1997 ; 1998$ \\
\hline Dep Ratio & 24.102 & 16.365 & 11.204 & 8.210 & 4.680 & 2.414 & 1.095 & - \\
\hline \multicolumn{9}{|c|}{ South Korea } \\
\hline $\ln G Y$ & $208.211 *$ & $189.550 *$ & $74.021 *$ & $35.368 *$ & 8.104 & 4.630 & 3.124 & 1997; 1998 \\
\hline $\ln P c Y$ & $189.554 *$ & $155.150 *$ & $67.300^{*}$ & $51.471 *$ & 5.500 & 3.036 & 2.147 & 1998; 2009 \\
\hline Dep Ratio & 20.025 & 16.457 & 7.028 & 6.320 & 5.411 & 3.205 & 1.007 & - \\
\hline
\end{tabular}


Table 8. Possible Explanations of the Break Dates

\begin{tabular}{|c|c|c|}
\hline Country & Break Dates & Possible Explanations \\
\hline China & $\begin{array}{l}1985(\mathrm{GH}, \mathrm{BP}) ; 1987(\mathrm{GH}) \\
1997(\mathrm{GH}) ; 1998(\mathrm{GH}, \mathrm{CS} \\
\mathrm{BP}) ; 1999(\mathrm{BP}) ; 2009(\mathrm{GH} \\
\mathrm{CS}, \mathrm{BP})\end{array}$ & $\begin{array}{l}\text { (1) 1983-1985: China experienced the rural reform boom } \\
\text { (2) 1985-1987: Industrial overheating correction. } \\
\text { (3) 1987-1988: China experienced faster growth in output that resulted in bank-panic inflation. } \\
\text { (4) 1984-1985: Chinese and British leaders signed the Chinese-British Joint Declaration. } \\
\text { (5) 1997-1999: Asian Financial Crisis. } \\
\text { (6) 2009: Great Recession. }\end{array}$ \\
\hline Hong Kong & $\begin{array}{l}1997(\mathrm{GH}, \mathrm{CS}, \mathrm{BP}) ; 1998 \\
(\mathrm{GH}, \mathrm{BP}) ; 2008(\mathrm{GH}) ; 2009 \\
(\mathrm{GH}, \mathrm{BP})\end{array}$ & $\begin{array}{l}\text { (1) 1997-1999: Return of Hong Kong to China. Asian Financial Crisis. } \\
\text { (2) 2008-2009: Great Recession. }\end{array}$ \\
\hline Japan & $\begin{array}{l}1989(\mathrm{GH}, \mathrm{BP}) ; 1992(\mathrm{GH} \\
\mathrm{BP}) ; 1997(\mathrm{BP}) ; 1998(\mathrm{GH} \\
\mathrm{CS}, \mathrm{BP}) ; 2008(\mathrm{GH}, \mathrm{BP}) \\
2009 \text { (CS) }\end{array}$ & $\begin{array}{l}\text { (1) 1989: Effect of the introduction of first national consumption tax of 3\%. Tokyo's stock bubble. } \\
\text { (2) 1992: The Japanese asset price bubble collapse. } \\
\text { (3) 1997-1998: Asian Financial Crisis. Japan's banking crisis. } \\
\text { (4) 2008-2009: Great Recession. }\end{array}$ \\
\hline South Korea & $\begin{array}{l}1997(\mathrm{BP}) ; 1998(\mathrm{GH}, \mathrm{CS} \\
\mathrm{BP}) ; 2002(\mathrm{GH}) ; 2003(\mathrm{GH}) \\
2008 \text { (CS); } 2009(\mathrm{GH}, \mathrm{BP})\end{array}$ & $\begin{array}{l}\text { (1) 1997-1998: Asian Financial Crisis. } \\
\text { (2) 2002: Typhoon Rusa, the worst typhoon to hit South Korea in } 40 \text { years. Battle between South Korean and } \\
\text { North Korean naval vessels. } \\
\text { (3) 2002-2003: Instability on money market which was influenced by the US's military strike on Iraq. } \\
\text { (4) 2008-2009: Great Recession. }\end{array}$ \\
\hline
\end{tabular}

Notes: GH stands for Gregory and Hansen, BP stands for Bai and Perron, and CS stands for Carrion-i-Silvestre and Sanso. 